\title{
Avoidable tracheal injury using a double-lumen endotracheal tube: a case report
}

\author{
Judith Lemay, MD · Massimo Conti, MD · Jacques Somma, MD, BEng $\cdot$ Louise Vigneault, MD, BSc • \\ Jean S. Bussières, MD, FRCPC
}

Received: 25 May 2017/Revised: 6 January 2018/Accepted: 8 January 2018/Published online: 24 January 2018

(C) Canadian Anesthesiologists' Society 2018

\section{To the Editor,}

The incidence of iatrogenic tracheobronchial injuries after intubation is estimated to be $1 / 20,000$. Double-lumen endotracheal tubes (DLT) were placed in half of such injuries. ${ }^{1}$ We report the presentation and management of a DLT-associated tracheal injury.

A 63-yr-old female, who consented to this report, was scheduled for video-assisted thoracoscopic right upper lobectomy. After induction of general anesthesia, a 37-Fr left DLT was inserted with a GlideScope ${ }^{\circledR}$ and GlideRite DLT Stylet ${ }^{\circledR}$ (Verathon Inc, Oakville, ON, Canada). The guide was withdrawn after the tip of the tube had passed the vocal cords. The DLT was blindly advanced $1-2 \mathrm{~cm}$ into the trachea, rotated $90^{\circ}$ counter-clockwise, and then advanced further until resistance was felt. Flexible bronchoscopy performed in both tracheal and bronchial lumens was reported as normal. The patient was positioned in the left lateral decubitus position with bronchoscopy again used to confirm the DLT position.

At pleural opening, lung isolation was found to be inadequate. The bronchoscope was reinserted in the tracheal lumen and the tube was withdrawn into the trachea. At this point, the anesthesiologist realized that both orifices of the DLT had been initially inserted in the right mainstem bronchus. The DLT was turned $90^{\circ}$ counter-clockwise and reinserted into the left main bronchus under bronchoscopic guidance. Neither blood nor tracheal laceration was noted.

J. Lemay, MD · M. Conti, MD · J. Somma, MD, BEng

L. Vigneault, MD, BSc · J. S. Bussières, MD, FRCPC $(\square)$

Institut universitaire de cardiologie et de cardiologie de Québec,

Québec, QC, Canada

e-mail: jbuss@criucpq.ulaval.ca
After surgery, the patient was easily re-intubated with a single-lumen 7.5-mm internal diameter endotracheal tube. During subsequent bronchoscopy, we discovered a $4-\mathrm{cm}-$ long tracheal laceration on the left side of the trachea, at the junction of the posterior (pars membranacea) and cartilaginous aspect. Computed tomography (CT) scan revealed a $39 \mathrm{~mm} \times 22 \mathrm{~mm}$ posterior tracheal laceration, $11 \mathrm{~mm}$ from the carina (Figure a), without air or blood in the mediastinum. The team opted for conservative management and the patient was extubated without incident. The following day, an oral contrast CT scan confirmed the integrity of the esophagus. Bronchoscopy five days after surgery showed fibrinous tissue in the wound and the esophagus bulging into the trachea with coughing. Two months after surgery, bronchoscopy showed healing by a well-defined scar (Figure b).

Blind insertion of a DLT is a common technique; however, misplacement of a left DLT in the right mainstem bronchus was reported in $48(4.2 \%)$ of 1,135 consecutive patients in a single centre study. ${ }^{2}$ Subsequent manipulations of DLTs are another risk factor for tracheal trauma. ${ }^{3}$ It is the authors' opinion that moving a DLT while the patient is in the lateral decubitus position is more difficult and traumatic and we suspect that was the mechanism of the injury described here.

We advocate the use of flexible bronchoscopy through the bronchial lumen for the primary positioning of both left and right DLTs. This technique minimizes misinterpretation of bronchial anatomy that may occur when DLTs are advanced blindly.

Case series support conservative management of tracheal lacerations ${ }^{4}$; a systematic review describes indications for conservative management. ${ }^{1}$ Healing of such injuries can be expected to take up to four weeks. ${ }^{4}$ Airway stenting has been recently suggested for 

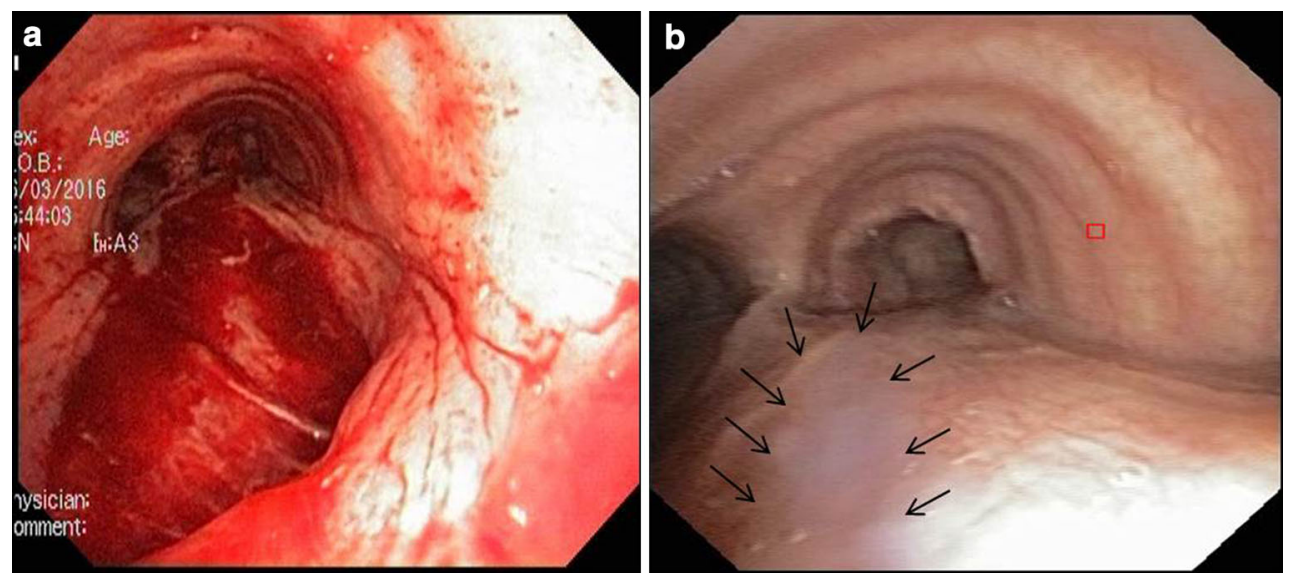

Figure Fibreoptic view of the tracheal laceration: a) Immediate postoperative period: 4-cm-long posterior laceration of the trachea. The laceration begins mid trachea and ends $1 \mathrm{~cm}$ from the carina. b) Two months postoperative: arrows mark a well-defined scar at the site of injury

management of mechanically ventilated patients with lower endotracheal injury. ${ }^{5}$

Tracheal laceration is a rare complication of DLT insertion. Endotracheal tube size should be chosen according to airway measurements. Excellent working knowledge of the bronchial anatomy is essential for tube placement. Further studies are needed to confirm that DLT positioning under bronchoscopic guidance offers advantages over blind insertion techniques. Conservative management of tracheal laceration should be considered first.

\section{Conflicts of interest None declared.}

Editorial responsibility This submission was handled by Dr. Gregory L. Bryson, Deputy Editor-in-Chief, Canadian Journal of Anesthesia.

\section{Financial disclosure None.}

\section{References}

1. Minambres E, Buron J, Ballesteros MA, Llorca J, Munoz P, Gonzalez-Castro A. Tracheal rupture after endotracheal intubation: a literature systematic review. Eur J Cardiothorac Surg 2009; 35: 1056-62.

2. Seo JH, Bae JY, Kim HJ, Hong DM, Jeon Y, Bahk JH. Misplacement of left-sided double-lumen tubes into the right mainstem bronchus: incidence, risk factors and blind repositioning techniques. BMC Anesthesiol 2015; 15: 157.

3. Fitzmaurice $B G$, Brodsky $J B$. Airway rupture from double-lumen tubes. J Cardiothorac Vasc Anesth 1999; 13: 322-9.

4. Conti M, Pougeoise M, Wurtz A, et al. Management of postintubation tracheobronchial ruptures. Chest 2006; 130: 412-8.

5. Tazi-Mezalek R, Musani AI, Laroumagne S, et al. Airway stenting in the management of iatrogenic tracheal injuries: 10-year experience. Respirology 2016; 21: 1452-8. 